\title{
PERILAKU HIDUP SEHAT MEMBERS FITNESS CENTER GOR FIK UNY
}

\section{Oleh: Eko Sucipto dan Suryanto FIK UNY}

\section{Abstrak}

Perilaku hidup sehat merupakan salah satu upaya untuk meningkatkan dan mempertahankan kesehatan. Seiring dengan perkembangan jaman, banyak orang yang berperilaku hidup kurang sehat terutama berkenaan dengan gaya hidup atau life style seperti minum minuman beralkohol, mengkonsumsi makanan yang tidak sehat, tidur tidak teratur, dan kurang berolahraga. Penelitian ini betujuan untuk mengetahui perilaku hidup sehat members Fitness Center Gedung Olahraga Fakultas Ilmu Keolahragaan Universitas Negeri Yogyakarta (GOR FIK UNY).

Penelitian ini merupakan penelitian deskriptif. Populasi penelitian adalah members Fitness Center GOR FIK UNY. Sampel penelitian ini adalah members Fitness Center yang masih aktif sebanyak 50 orang. Teknik pengambilan sampel menggunakan accidental sampling atau teknik sampling kebetulan, maksudnya adalah apabila pemilihan anggota sampelnya dilakukan terhadap orang yang berbeda atau benda yang kebetulan ada atau dijumpai. Pengumpulan data menggunakan angket. Hasil uji validitas diketahui dari 32 butir angket terdapat 4 butir yang gugur yaitu nomor $6,17,22$ dan 30 yang selanjutnya tidak digunakan dalam pengambilan data penelitian. Hasil uji reliabilitas diperoleh koefisien reliabilitas sebesar 0,925 dan dinyatakan reliabel. Analisis data menggunakan analisis deskriptif dengan presentase.

Hasil penelitian diketahui perilaku hidup sehat members fitness center GOR FIK UNY dalam kategori cukup baik sebanyak $72 \%$. Perilaku terhadap makanan dan minuman sebagian besar responden dalam kategori baik dan cukup baik. Perilaku terhadap kebersihan diri sebagian besar responden dalam kategori Baik. Perilaku terhadap kebersihan lingkungan sebagian besar responden dalam kategori cukup baik. Perilaku terhadap sakit dan penyakit sebagian besar responden dalam kategori cukup baik. Perilaku hidup yang teratur sebagian besar responden dalam kategori cukup baik.

Kata kunci: perilaku hidup sehat, members fitness

Setiap members of fitness center ingin menerapkan perilaku hidup sehat, baik diterapkan di rumah maupun di tempat umum khususnya di fitness center itu sendiri. Members of fitness center juga ingin hidupnya sehat baik dirinya sendiri maupun di sekitarnya. Penyelenggaraan upaya kesehatan mempunyai tujuan untuk mencapai kemampuan hidup sehat setiap members. Salah satu contoh dari keseharian members yang belum mencerminkan perilaku sehat, misalnya ketika seorang selesai latihan tidak membersihkan tubuhnya dahulu, melainkan masih melakukan aktivitas yang lain, 


\section{MEDIKORA Vol. XIV No. 1April 2015}

sehingga gaya hidup sehatnya akan terganggu dan mudah terserang penyakit. Untuk mencapai kesehatan perlu didukung oleh perilaku hidup sehat members itu sendiri, baik itu pola makan, pola istirahat, dan perilaku terhadap sakit dan penyakit.

Perilaku hidup sehat adalah sebagai penunjang tercapainya kebersihan pribadi members fitness center GOR FIK UNY, apabila members sudah menerapkan perilaku hidup sehat dengan baik, diharapkan kondisi kesehatan dan kebugaran members dapat meningkat sesuai dengan apa yang diinginkan members. Perilaku hidup sehat merupakan wujud nyata kehidupan manusia dengan menerapkan gaya hidup yang sehat. Dengan dapat menerapkan perilaku hidup sehat secara berkesinambungan seorang members sudah dapat memperoleh manfaat yang sangat besar, selain terciptanya kondisi badan yang sehat dan terhindar dari sakit dan penyakit. Kesehatan lingkungan merupakan masalah penting untuk ketahanan tubuh setiap individu (pribadi) terhadap faktor-faktor yang mengganggu kesehatannya.

Perilaku gaya hidup members selalu berupaya memelihara dan meningkatkan kesehatan pribadi dengan menerapkan perilaku hidup sehat, yaitu: (1) memperhatikan pola makan, asupan gizi, pemilihan bahan makanan serta kebersihan makanan, hal ini sangat penting agar kebutuhan akan zat-zat yang diperlukan tubuh untuk beraktivitas dapat tercukupi dengan baik, (2) menjaga kebersihan badan, selain untuk menjaga kesehatan kebersihan diri juga bermanfaat, agar selalu tampil menarik karena pada usia dewasa sudah memiliki kemajuan dalam berpikir, memiliki rasa malu serta ketertarikan terhadap lawan jenis, (3) kebersihan lingkungan, kepedulian members terhadap kebersihan lingkungan menunjukkan bahwa members tersebut memiliki kepribadian yang sehat, (4) perilaku terhadap sakit dan penyakit, kesehatan seseorang sangat mempengaruhi produktivitas orang tersebut, sehingga bila diterapkan pada seorang members kesehatan sangat mempengaruhi perilaku hidup sehat member, (5) berolahraga secara rutin, agar kondisi kebugaran tubuh dapat terjaga atau pun dapat ditingkatkan.

Perubahan-perubahan gaya hidup yang terjadi pada members Fitness Center memerlukan olahraga dan mengantisipasi gaya hidup yang tidak sehat seperti merokok, minum-minuman keras, dan menghindari makanan yang mengandung banyak lemak gula atau garam, perubahan gaya hidup karena mereka ingin mempunyai waktu luang 


\section{MEDIKORA Vol. XIV No. 1April 2015}

untuk berolahraga, rekreasi serta mengembangkan hobi yang bermanfaat.

Kesehatan members pada dasarnya dapat dipengaruhi oleh faktor lingkungan, upaya kesehatan, dan perilaku. Faktor lingkungan tentunya members dapat mengubah perilakunya menjadi lebih baik, dalam arti bahwa sesuatu lingkungan dapat mempengaruhi perilaku yang tidak baik, sehingga members dapat menghindari dari perilaku yang kurang baik. Dengan perilaku yang sehat serta dengan mengubah sikap dan perilaku seseorang members perilaku terhadap makanan dan minuman, perilaku terhadap kebersihan diri, perilaku terhadap kebersihan lingkungan, perilaku terhadap sakit dan penyakit, dan perilaku hidup yang teratur, members akan dapat memperoleh kondisi kesehatan yang baik. Untuk mencapai kondisi fisik yang optimal salah satunya diperlukan kondisi kesehatan yang optimal. Oleh sebab itu kondisi kesehatan yang baik harus dimulai sejak dini, dengan menanamkan kesadaran diri tiap individu atau keluarga dalam masyarakat untuk mengupayakan hidup sehat dalam kehidupan sehari-hari, disertai dengan upaya atau keinginan untuk mempertahankan kondisi fisik.

Konsultasi berlanjut para members dilakukan secara bertahap kepada instruktur fitness center karena untuk konsultasi masalah kesehatan khusus belum ada, sehingga dapat dikonsultasikan kepada instruktur. Konsultasi ini bertujuan untuk mengetahui perilaku hidup sehat members dan gangguan kesehatan. Oleh karena itu, perilaku hidup sehat members di GOR FIK UNY perlu diketahui secara dini, sehingga kesehatan members dapat dipertahankan pada taraf setinggi-tingginya dan terhindar dari penyakit dan gangguan, sehingga members Fitness Center dapat hidup dengan kualitas yang baik.

Dalam penelitian ini, peneliti berusaha meneliti perilaku hidup sehat dari members Fitness Center GOR FIK UNY, yaitu perilaku terhadap makanan dan minuman, perilaku terhadap kebersihan diri, perilaku terhadap kebersihan lingkungan, perilaku terhadap sakit dan penyakit, dan perilaku hidup yang teratur, sehingga dengan hasil penelitian ini dapat digunakan sebagai pertimbangan untuk mempertahankan kesehatan Members Fitness Center GOR FIK UNY.

\section{Pengertian Perilaku}

Dari segi biologis, perilaku merupakan aktivitas organisme yang mempunyai bentangan yang luas. Menurut Soekidjo (2007: 133) yang dimaksud perilaku adalah semua kegiatan atau aktivitas manusia baik yang dapat diamati langsung maupun yang 


\section{MEDIKORA Vol. XIV No. 1April 2015}

tidak dapat diamati langsung.

Menurut Solita Sarwono (1993: 1) perilaku manusia merupakan hasil dari segala macam pengalaman serta interaksi manusia dengan lingkungannya yang terwujud dalam bentuk pengetahuan, sikap dan tindakan. Dengan demikian, perilaku adalah respons/reaksi seorang individu terhadap sitimulus yang berasal atau dari dalam dirinya.

Para ahli mengatakan bahwa perilaku sama dengan tindakan atau aktivitas yang dilakukan individu akibat adanya stimulus atau rangsangan dari luar, sedangkan menurut M. Ichsan yang dikutip oleh Samsu (2006: 14) perilaku adalah suatu proses keadaan mental yang mendorong seseorang untuk melakukan sesuatu.

Menurut Bimo Walgio (2003: 10) perilaku itu sebagai aktivitas- aktivitas yang merupakan manifestasi kehidupan psikis. Perilaku (aktivitas) yang ada dalam individu tidak timbul dengan sendirinya, tetapi sebagai akibat dari adanya rangsangan yang mengenai individu itu. Perilaku merupakan jawaban terhadap rangsangan yang mengenai dan perilaku organism itu tidak dapat lepas dari pengaruh lingkungan dan organisme itu sendiri

Menurut Soekidjo (1993: 120) perilaku dibedakan menjadi dua macam, yaitu:

1) Perilaku Pasif

Perilaku pasif adalah respon internal, yaitu yang terjadi di dalam diri manusia dan tidak secara langsung dapat dilihat oleh orang lain, misalnya berpikir, tanggapan atau sikap batin dan pengetahuan. Seperti seorang members fitness tahu bahwa dengan pengaturan istirahat yang baik setelah latihan akan membuat kondisi tubuh tetap terjaga kesehatannya, dan anggota masih dapat mengerjakan aktivitas yang lain, contohnya membaca koran atau yang lainnya.

2) Perilaku Aktif

Prilaku aktif yaitu apabila prilaku itu jelas dapat diobservasikan secara langsung. Misalnya anggota sudah bisa mengatur waktu istirahat dengan waktu latihan, sehingga kondisi tubuh tetap terjaga. Bloom yang dikutip oleh Solita Sawono (1993: 2) membedakan perilaku menjadi tiga, yaitu: perilaku kognitif (yang menyangkut kesadaran atau pengetahuan), afektif (emosi), dan psikomotor (tindakan/gerakan).

Sikap dapat dirumuskan sebagai kecendrungan untuk merespons (secara positif atau negatif) terhadap orang, objek atau situasi tertentu. Sikap mengandung suatu 


\section{MEDIKORA Vol. XIV No. 1April 2015}

penilaian emosional/afektif (senang, benci, sedih dan lain-lain), di samping komponen kognitif (pengetahuan tentang objek itu), sedangkan pengetahuan lebih bersifat pengenalan suatu benda/hal secara objektif. Selain bersifat negatif dan positif, sikap memeliki tingkat kedalaman yang berbeda-beda

Menurut Benyamin Bloom yang dikutip M. Ichan (1988: 11) ada tiga aspek dasar yang mempengaruhi perilaku, yaitu:

1) Aspek Pengetahuan (Cognitif Domain)

Aspek ini merupakan aspek dasar dalam perubahan perilaku seseorang. Aspek ini berkembang secara bertahap memahami, yang kemudian berlanjut ke tahap mengetahui, menganalisa, mensintensa dan menilai. Aspek ini melatarbelakangi lahirnya aspek sikap.

2) Aspek Sikap (Afektif Domain)

Aspek sikap adalah suatu proses perkembangan mental dalam menentukan pilihan untuk menerima atau menolak suatu rangsangan dari luar diri seseorang setelah ia mengalami proses perkembangan mental aspek pengetahuan. Seperti halnya aspek pengetahuan, aspek sikap juga berkembang melalui beberapa tahap menerima, dan menolak. Kedua tahap ini bersifat kontras sebagai kedua pilihan yang menentukan. Dalam proses perkembangan, kedua tahap yang kontras tersebut terjadi perkembangan menerima, merasakan, menjawab, kemudian menetukan sikap menolak dan menerima. Setelah aspek sikap ini berkembang, kemudian lahir aspek selanjutnya yaitu aspek perbuatan.

3) Aspek Perbuatan (Psikomotor Domain)

Aspek perbuatan merupakan tahap selanjutnya dari aspek pengetahuan dan aspek sikap. Dalam proses perkembangannya, aspek perbuatan akan sampai pada tahap berbuat untuk melakukan sesuatu.

Jadi dalam perubahan perilaku dari mulai timbulnya perkembangan pengetahuan (kognitif) yang kemudian diikuti perkembangan bersikap (afektif) dan sampai pada tindakan atau perilaku (psikomotor), sehingga perilaku hidup sehat yang diinginkan akan tercapai apabila didasari oleh: (1) pengetahuan, (2) sikap, sebagai perwujudan sikap mental dan cerminan dari wawasan yang dimiliki juga dasar di dalam mengambil keputusan, dan (3) perbuatan dalam melakukan aktivitas sehari-hari hendaknya senantiasa berpedoman pada aturan-aturan yang sesuai dengan syarat-syarat kesehatan. 


\section{MEDIKORA Vol. XIV No. 1April 2015}

\section{Pengertian Hidup Sehat}

Batasan atau arti sehat secara umum dikemukakan oleh World Health Organization (WHO) yang dikutip oleh Soekidjo (2007: 3) sehat adalah keadaan sempurna, baik fisik, mental, maupun sosial, dan tidak hanya bebas dari penyakit dan cacat. Undang-Undang Kesehatan No. 23 Tahun 1992 memberikan batasan kesehatan adalah keadaan sejahtera badan, jiwa, dan sosial yang memungkinkan setiap orang hidup produktif secara sosial dan ekonomi (Soekidjo, 2007: 3). Menurut Kus Irianto dan Kusno Waluyo (2004: 84) sehat merupakan masa tumbuh kembang manusia, mencakup manusia seutuhnya, meliputi fisik, emosi, sosial, dan spiritual. Sehat bukan hanya bebas dari penyakit, tetapi meliputi seluruh kehidupan manusia, termasuk aspek sosial, psikologis, spiritual, faktor-faktor lingkungan, ekonomi, pendidikan dan rekreasi.

Menurut Wibowo (1991: 2) sehat adalah sehat pribadi seorang seutuhnya, meliputi sehat fisik, sehat mental dan sehat sosial yang ketiganya tidak dapat dipisahkan, sedangkan sakit adalah suatu keadaan yang disebabkan oleh bermacam-macam hal, bisa suatu kejadian, kelainan yang dapat menimbulkan gangguan terhadap susunan jaringan tubuh, baik fungsi jaringan itu maupun fungsi keseluruhan. Samsu (2006:15) perilaku sehat adalah setiap tindakan yang mempengaruhi peluang secara langsung atau jangka panjang semua konsekuensi fisik yang menjadi lebih baik.

\section{METODE PENELITIAN}

Penelitian ini merupakan penelitian deskriptif karena hanya sampai taraf menggambarkan keadaan objek, yaitu bagaimana perilaku hidup sehat members fitness center GOR FIK UNY. Populasi dalam penelitian ini adalah members fitness center GOR FIK UNY. Sampel penelitian ini adalah members fitness center GOR FIK UNY yang masih aktif. Dari jumlah data yang terdaftar di fitness, yaitu 250 members Dilihat dari jumlah data yang terdaftar di fitness center dapat diketahui members yang aktif melakukan fitness sebanyak 50, sehingga peneliti mengambil sampel sebanyak 50 members. Teknik pengambilan sampel menggunakan sampling nonrandom kebetulan (accidental sampling). Instrumen penelitian dalam penelitian ini menggunakan satu instrumen yang berbentuk angket tertutup, yaitu digunakan sebagai alat pengukuran data tentang perilaku hidup sehat members fitness center GOR FIK UNY.

Teknik analisis data yang digunakan dalam penelitian ini adalah analisis data deskriptif dengan persentase (Suharsimi Arikunto, 1993: 140-141). Angka yang 


\section{MEDIKORA Vol. XIV No. 1April 2015}

diperoleh dijumlahkan dan hasilnya dibandingkan dengan jumlah skor yang diharapkan, sehingga diperoleh persentase. Selanjutnya angka persentase ditafsirkan ke dalam kalimat yang bersifat komulaif.

\section{HASIL PENELITIAN}

Penelitian ini dilaksanakan di fitness center GOR Fakultas Ilmu Keolahragaan Universitas Negeri Yogyakarta yang beralamat di Jl. Kolombo No. 1 Yogyakarta. Subjek penelitian ini adalah members fitness center GOR Fakultas Ilmu Keolahragaan Universitas Negeri Yogyakarta sebanyak 50 orang.

Hasil analisis deskriptif pada data penelitian dan faktor-faktor perilaku hidup sehat adalah sebagai berikut:

Tabel 1. Hasil Analisis Deskriptif Perilaku Hidup Sehat

\begin{tabular}{|c|c|c|c|c|c|c|}
\hline Data & Min & Max & Mean & Median & Modus & Std. Dev \\
\hline Perilaku hidup sehat & 69,00 & 95,00 & 82,58 & 83,00 & 81,00 & 5,47 \\
\hline
\end{tabular}

Perilaku hidup sehat di dalamnya terdapat lima faktor yaitu perilaku terhadap makanan dan minuman, perilaku terhadap kebersihan diri, perilaku terhadap kebersihan lingkungan, perilaku terhadap sakit dan penyakit serta perilaku hidup yang teratur. Hasil analisis deskriptif pada masing-masing faktor adalah sebagai berikut:

Tabel 2. Hasil Analisis Deskriptif Faktor-faktor Perilaku Hidup Sehat

\begin{tabular}{|l|c|c|c|c|c|c|}
\hline \multicolumn{1}{|c|}{ Data } & Min & Max & Mean & Median & Modus & Std. Dev \\
\hline $\begin{array}{l}\text { Perilaku terhadap makanan dan } \\
\text { Minuman }\end{array}$ & 12,00 & 22,00 & 17,90 & 18,00 & 17,00 & 2,62 \\
\hline Perilaku terhadap kebersihan diri & 12,00 & 20,00 & 16,56 & 16,00 & 16,00 & 2,21 \\
\hline $\begin{array}{l}\text { Perilaku terhadap kebersihan } \\
\text { lingkungan }\end{array}$ & 10,00 & 19,00 & 15,30 & 15,00 & 14,00 & 1,92 \\
\hline $\begin{array}{l}\text { Perilaku terhadap sakit dan } \\
\text { penyakit }\end{array}$ & 7,00 & 15,00 & 11,14 & 11,00 & 11,00 & 1,51 \\
\hline Perilaku hidup yang teratur & 17,00 & 28,00 & 21,68 & 21,50 & 20,00 & 2,54 \\
\hline
\end{tabular}


Hasil kategorisasi data perilaku hidup sehat dapat dilihat pada tabel berikut:

Tabel 3. Kategorisasi Data Perilaku Hidup Sehat

\begin{tabular}{|c|c|c|c|}
\hline $\begin{array}{c}\text { Interval \% } \\
\text { Slar }\end{array}$ & Frekuensi & Persentase (\%) & Kategori \\
\hline $76 \%-100 \%$ & 1 & 28,0 & Baik \\
\hline $56 \%-75 \%$ & 4 & 72,0 & Cukup baik \\
\hline $41 \%-55 \%$ & 0 & 0,0 & Kurang baik \\
\hline$<40 \%$ & 0 & 0,0 & Tidak baik \\
\hline Total & 5 & 100,0 & \\
\hline
\end{tabular}

Berdasarkan tabel di atas diketahui sebanyak 14 orang $(28,0 \%)$ mempunyai perilaku hidup sehat kategori baik, sebanyak 36 orang (72,0\%) mempunyai perilaku hidup sehat kategori cukup baik. Tidak ada responden yang mempunyai perilaku hidup sehat kategori kurang baik dan tidak baik.

Hasil kategorisasi data pada masing-masing faktor perilaku hidup sehat meliputi perilaku terhadap makanan dan minuman, perilaku terhadap kebersihan diri, perilaku terhadap kebersihan lingkungan, perilaku terhadap sakit dan penyakit serta perilaku hidup teratur adalah sebagai berikut.

1. Perilaku terhadap Makanan dan Minuman

Hasil pengkategorian faktor perilaku terhadap makanan dan minuman dapat dilihat pada tabel berikut:

Tabel 4. Kategorisasi Data Perilaku terhadap Makanan dan Minuman

\begin{tabular}{|c|c|c|c|}
\hline Interval \% Skor & Frekuensi & Persentase (\%) & Kategori \\
\hline $76 \%-100 \%$ & 23 & 46,0 & Baik \\
\hline $56 \%-75 \%$ & 23 & 46,0 & Cukup baik \\
\hline $41 \%-55 \%$ & 4 & 8,0 & Kurang baik \\
\hline$<40 \%$ & 0 & 0,0 & Tidak baik \\
\hline Total & 50 & 100,0 & \\
\hline
\end{tabular}


2. Perilaku terhadap Kebersihan Dir

Hasil pengkategorian faktor perilaku terhadap kebersihan diri dapat dilihat pada tabel berikut:

Tabel 5. Kategorisasi Data Perilaku terhadap Kebersihan Diri

\begin{tabular}{|c|c|c|c|}
\hline Interval \% Skor & Frekuensi & Persentase ( \%) & Kategori \\
\hline $76 \%-100 \%$ & 34 & 68,0 & Baik \\
\hline $56 \%-75 \%$ & 16 & 32,0 & Cukup baik \\
\hline $41 \%-55 \%$ & 0 & 0,0 & Kurang baik \\
\hline$<40 \%$ & 0 & 0,0 & Tidak baik \\
\hline Total & 50 & 100,0 & \\
\hline
\end{tabular}

3. Perilaku terhadap Kebersihan Lingkungan

Hasil pengkategorian faktor perilaku terhadap kebersihan lingkungan dapat dilihat pada tabel berikut:

Tabel 6. Kategorisasi Data Perilaku terhadap Kebersihan Lingkungan

\begin{tabular}{|c|c|c|c|}
\hline Interval \% Skor & Frekuensi & Persentase (\%) & Kategori \\
\hline $76 \%-100 \%$ & 24 & 48,0 & Baik \\
\hline $56 \%-75 \%$ & 25 & 50,0 & Cukup baik \\
\hline $41 \%-55 \%$ & 1 & 2,0 & Kurang baik \\
\hline$<40 \%$ & 0 & 0,0 & Tidak baik \\
\hline Total & 50 & 100,0 & \\
\hline
\end{tabular}

Berdasarkan tabel di atas diketahui sebanyak 24 orang $(48,0 \%)$ mempunyai perilaku terhadap kebersihan lingkungan dalam kategori baik, sebanyak 25 orang $(50,0$ \%) mempunyai perilaku terhadap kebersihan lingkungan dalam kategori cukup baik. Sebanyak 1 orang (2\%) mempunyai perilaku terhadap kebersihan lingkungan kategori kurang baik dan tidak ada responden yang mempunyai perilaku terhadap kebersihan lingkungan kategori tidak baik.

Distribusi frekuensi perilaku terhadap kebersihan lingkungan dapat dilihat pada gambar berikut:

4. Perilaku terhadap Sakit dan Penyakit 
Hasil pengkategorian faktor perilaku sakit dan penyakit dapat dilihat pada tabel berikut:

Tabel 7. Kategorisasi Data Perilaku Terhadap Sakit dan Penyakit

\begin{tabular}{|c|c|c|l|}
\hline Interval \% Skor & Frekuensi & Persentase ( \%) & \multicolumn{1}{|c|}{ Kategori } \\
\hline $76 \%-100 \%$ & 8 & 16,0 & Baik \\
\hline $56 \%-75 \%$ & 40 & 80,0 & Cukup baik \\
\hline $41 \%-55 \%$ & 2 & 4,0 & Kurang baik \\
\hline$<40 \%$ & 0 & 0,0 & Tidak baik \\
\hline Total & 50 & 100,0 & \\
\hline
\end{tabular}

Berdasarkan tabel di atas diketahui sebanyak 8 orang $(16,0 \%)$ mempunyai perilaku terhadap sakit dan penyakit dalam kategori baik, sebanyak 40 orang $(80,0 \%)$ mempunyai perilaku terhadap sakit dan penyakit dalam kategori cukup baik. Sebanyak 1 orang ( $4 \%$ ) mempunyai perilaku terhadap sakit dan penyakit kategori kurang baik dan tidak ada responden yang mempunyai perilaku terhadap sakit dan penyakit kategori tidak baik.

5. Perilaku Hidup yang Teratur

Hasil pengkategorian faktor perilaku hidup yang teratur dapat dilihat pada tabel berikut:

Tabel 8. Kategorisasi Data Perilaku Terhadap Hidup yang Teratur

\begin{tabular}{|c|c|c|c|}
\hline Interval \% Skor & Frekuensi & Persentase ( \%) & Kategori \\
\hline $76 \%-100 \%$ & 8 & 16,0 & Baik \\
\hline $56 \%-75 \%$ & 41 & 82,0 & Cukup baik \\
\hline $41 \%-55 \%$ & 1 & 2,0 & Kurang baik \\
\hline$<40 \%$ & 0 & 0,0 & Tidak baik \\
\hline Total & 50 & 100,0 & \\
\hline
\end{tabular}

Berdasarkan tabel di atas diketahui sebanyak 8 orang $(16,0 \%)$ mempunyai perilaku hidup yang teratur dalam kategori baik, sebanyak 41 orang $(82,0 \%)$ mempunyai perilaku hidup yang teratur dalam kategori cukup baik. Sebanyak 1 orang (2\%) mempunyai perilaku hidup yang teratur kategori kurang baik dan tidak 


\section{MEDIKORA Vol. XIV No. 1April 2015}

ada responden yang mempunyai perilaku hidup yang teratur kategori tidak baik.

\section{PEMBAHASAN}

Penelitian ini bertujuan untuk mengetahui perilaku hidup sehat members fitness center GOR FIK UNY. Hasil analisis data diketahui perilaku hidup sehat sebagian besar members fitness center COR FIK UNY sebagian besar dalam kategori cukup baik sebanyak $72 \%$. Hasil ini dapat diartikan bahwa members fitness center telah melakukan perilaku yang cukup baik untuk menjaga kesehatannya. Perilaku hidup sehat merupakan bentuk tindakan nyata untuk mempertahankan dan meningkatkan kesehatannya. Perilaku hidup sehat dapat terbentuk dengan adanya kesadaran dari dalam diri seseorang akan pentingnya berperilaku hidup sehat. Perilaku hidup sehat yang dilakukan seseorang akan dapat mempertahankan atau memelihara dan memperbaiki kesehatan.

Members fitness center sangat penting untuk melakukan perilaku hidup sehat. Hal ini disebabkan aktivitas members dalam menjaga kebugaran jasmani melalui olahraga harus dimaksimalkan dengan menerapkan perilaku hidup sehat dalam kehidupan sehari-hari. Perilaku hidup sehat tersebut mencakup perilaku terhadap makanan dan minuman, perilaku terhadap kebersihan diri, perilaku terhadap kebersihan lingkungan, perilaku terhadap sakit dan penyakit serta perilaku hidup yang teratur.

Hasil analisis pada perilaku terhadap makanan dan minuman diketahui sebagian besar responden mempunyai perilaku yang baik dan cukup baik masing-masing sebesar $46 \%$. Hasil ini dapat diartikan bahwa members telah mempunyai kemampuan yang baik dalam mememilih jenis makanan dan minuman yang dikonsumsinya. Individu membutuhkan asupan nutrisi untuk memenuhi kebutuhan energi yang digunakan untuk melakukan aktivitas sehari-hari. Kebutuhan nutrisi ini dapat terpenuhi melalui makanan maupun minuman yang dikonsumsi oleh seseorang. Perilaku terhadap makanan dan minuman yang baik ditunjukkan dengan pola konsumsi makanan dan minuman yang mengandung nutrisi dan gizi sesuai dengan kebutuhan tubuh. Terpenuhinya kebutuhan gizi tubuh akan dapat mempertahankan derajat kesehatan seseorang. Sesuai dengan Soekidjo (2007: 136) yang menyebutkan makanan dan minuman yang baik dapat memelihara dan meningkatkan kesehatan seseorang.

Perilaku hidup sehat juga ditunjukkan dengan perilaku terhadap kebersihan diri. Hasil analisis diketahui perilaku terhadap kebersihan diri members fitness center sebagian besar dalam kategori baik sebanyak $68 \%$. Hasil ini dapat diartikan bahwa members fitness telah 


\section{MEDIKORA Vol. XIV No. 1April 2015}

melakukan perilaku menjaga kebersihan diri dengan baik. Perilaku terhadap kebersihan diri diwujudkan dalam aktivitas keseharian seperti mandi teratur, menjaga kebersihan kulit, mata, kuku, telinga, hidung termasuk juga menjaga kebersihan pakaian yang digunakan. Kemampuan berperilaku terhadap kebersihan diri akan mampu memelihara derajat kesehatan seseorang. Seperti yang dikemukakan oleh Sjarifudin (1979: 2) menyebutkan menjaga kesehatan diri merupakan bentuk usaha menjaga kesehatan diri sendiri.

Aspek yang tidak kalah penting dalam perilaku hidup sehat adalah kebersihan lingkungan. Hasil analisis perilaku terhadap kebersihan lingkungan members fitness center diketahui sebagian besar mempunyai perilaku terhadap kebersihan lingkungan dalam kategori cukup baik sebanyak 50 \%. Dapat diartikan bahwa kesadaran terhadap kebersihan lingkungan masih cukup. Perilaku menjaga kebersihan lingkungan terbentuk dari kebiasaan yang dimulai sejak kecil. Kebiasaan yang baik akan terbawa sampai dewasa yang diwujudkan dalam bentuk nyata menjaga kebersihan lingkungan. Perilaku yang buruk akan menyebabkan terganggunya kesehatan members fitness.

Hasil analisis pada perilaku terhadap sakit dan penyakit diketahui sebagian besar members fitness mempunyai perilaku cukup baik sebanyak 80 \%. Menurut Soekidjo (1993: 59) perilaku terhadap sakit dan penyakit meliputi perilaku meningkatkan dan memelihara kesehatan, perilaku pencegahan penyakit, perilaku pencarian pengobatan dan perilaku terhadap pemulihan kesehatan. Perilaku dalam kategori cukup menunjukkan bahwa responden belum sepenuhnya melakukan tindakan-tindakan nyata untuk menghindarkan diri dari penyakit maupun cara untuk mengatasi sakit. Hal ini dapat disebabkan karena kurangnya pemahaman terhadap perilaku yang harus dilakukan terhadap sakit dan penyakit.

Perilaku hidup sehat disempurnakan dengan melakukan perilaku hidup yang teratur. Berdasarkan hasil analisis diketahui perilaku hidup yang teratur members fitness center sebagian besar dalam kategori cukup baik sebesar $82 \%$. Hidup yang teratur merupakan komponen penting terwujudnya kesehatan. Hidup yang teratur diantaranya teratur dalam pola makan, istirahat, berolahraga maupun teratur memeriksakan kesehatan diri. Perilaku hidup yang teratur dianggap sulit dilakukan oleh sebagian orang karena perilaku hidup teratur membutuhkan komitmen yang tinggi dan disiplin dari dalam diri individu untuk pola perilaku tersebut secara kontinyu.

Secara keseluruhan dapat disimpulkan bahwa perilaku hidup sehat members fitness center dalam kategori cukup baik. Perilaku hidup sehat yang paling baik dilakukan oleh members fitness center adalah faktor kebersihan diri. Hal ini dapat diartikan bahwa 


\section{MEDIKORA Vol. XIV No. 1April 2015}

members fitness center telah melakukan perilaku kebersihan diri dengan baik dalam kehidupan sehari-harinya. Kebersihan diri tersebut diwujudkan dalam perilaku mandi minimal dua kali sehari, menggosok gigi, mencuci tangan dan kaki menggunakan sabun, mencuci rambut, telinga, kuku secara rutin dan perilaku kebersihan diri yang lain. Seperti halnya yang dikemukakan oleh Depdikbud (1986: 23-30) yang menyebutkan ruang lingkup kebersihan pribadi mencakup perawatan fisik seperti perawatan kulit, mata, kuku, hidung telinga. Kebersihan diri merupakan faktor penting terwujudnya perilaku hidup sehat dan merupakan bentuk upaya untuk menjaga kesehatan diri.

Perilaku kebersihan diri dapat terbentuk dengan baik karena perilaku ini telah dibiasakan sejak kecil. Orang tua telah membiasakan anak untuk melakukan perilaku kebersihan diri. Kebiasaan melakukan kebersihan diri yang telah dilakukan sejak kecil akan terbawa sampai dewasa. Hal ini sesuai dengan Soekidjo (2007: 16) yang menyebutkan perilaku dapat terbentuk karena adanya faktor tradisi atau budaya yang dilakukan masyarakat berkaitan dengan kesehatan.

Faktor yang paling kurang dilakukan oleh members fitness center adalah perilaku hidup yang teratur. Hal ini dapat diartikan bahwa members fitness center belum sepenuhnya melakukan perilaku hidup yang teratur. Perilaku tersebut diantaranya ditunjukkan dengan pola tidur yang kurang baik yaitu tidur terlalu larut malam. Selain itu ditunjukkan pula dengan aktivitas olahraga yang belum rutin dilakukan, serta kurangnya pemenuhan terhadap kebutuhan rekreasi. Perilaku hidup yang tidak teratur dapat terjadi karena adanya pengaruh dari faktor lingkungan. Lingkungan pergaulan members fitness center memberikan kontribusi terhadap terbentuknya perilaku hidup yang dilakukan. Lingkungan yang kurang baik akan memberikan pengaruh yang kurang baik pula terhadap perilaku members fitness center, sehingga menyebabkan terbentuknya perilaku hidup yang tidak teratur. Sesuai dengan M. Ihsan yang dikutip oleh Samsu (2006: 16) menyebutkan faktor lingkungan mempengaruhi terbentuknya perilaku hidup sehat.

Hasil penelitian ini berimplikasi bahwa perilaku hidup sehat members perlu untuk ditingkatkan. Pembentukan perilaku diantaranya dapat dilakukan dengan pembiasaan. Seseorang yang membiasakan diri melakukan perilaku yang baik dalam menjaga kesehatan maka akan terbentuklah perilaku tersebut.

Perilaku hidup sehat juga dapat dibentuk melalui pemberian pengertian dan pemahaman. Hal ini dapat dilakukan melalui pemberian pendidikan kesehatan yang dapat dilakukan oleh 


\section{MEDIKORA Vol. XIV No. 1April 2015}

instruktur fitness tentang perilaku hidup sehat. Pemahaman members tentang perilaku hidup sehat akan membentuk perilaku yang baik. Sesuai dengan teori Bloom yang dikutip oleh M. Ichan (1988: 11) disebutkan bahwa pemahaman dan pengetahuan merupakan aspek dasar terbentuknya perilaku seseorang, dimana seseorang akan berperilaku sesuai dengan pengetahuan yang dimilikinya.

Perilaku hidup sehat sangat penting dalam mewujudkan derajad kesehatan seseorang. Members fitness yang dapat menerapkan perilaku hidup sehat dalam kehidupan sehari-hari secara berkesinambungan vakan memperoleh manfaat yaitu terwujudnya kondisi badan yang sehat serta terhindar dari sakit maupun penyakit. Semakin baik perilaku kesehatan yang dilakukan maka akan dicapai tingkat kesehatan yang lebih baik.

\section{KESIMPULAN}

Hasil penelitian menunjukkan bahwa secara keseluruhan perilaku hidup sehat members fitness center GOR FIK UNY dalam kategori cukup baik. Hasil ini berimplikasi bahwa perilaku hidup sehat members fitness center perlu untuk ditingkatkan. Perilaku yang perlu ditingkatkan terutama perilaku terhadap makanan dan minuman, perilaku kebersihan lingkungan, perilaku terhadap sakit dan penyakit dan perilaku hidup yang teratur. Peningkatan atau pembentukan perilaku dapat dilakukan dengan pembiasaan diri melakukan perilaku hidup sehat dan dapat juga dibentuk melalui pemberian pengetahuan tentang perilaku hidup sehat. Perilaku hidup sehat merupakan bentuk tindakan nyata yang dilakukan sebagai upaya untuk mempertahankan dan memelihara kesehatan. Perilaku hidup sehat yang dilakukan akan berdampak pada tercapainya derajat kesehatan.

\section{DAFTAR PUSTAKA}

Arikunto, S. (1993). Prosedur Penelitian suatu Pendekatan Praktik. Jakarta: rineka Cipta.

Bimo Walgito. (2003). Psikologi Sosial. Yogyakarta: Andi.

Depdikbud, (1983). Kesehatan Sekolah di Sekolah Dasar. Jakarta: Departemen Pendidikan dan Kebudayaan.

(1986). Tuntutan Pendidikan Kesehatan Perbadi. Jakarta: Departemen Pendidikan dan Kebudayaan.

Ichan, M. (1998). Pendidikan Kesehatan Olahraga. Jakarta: Dekdibud Dirjen Dekti Proyek Pengembangan Lembaga Pendidikan Tenaga Kependidikan. 
MEDIKORA Vol. XIV No. 1April 2015

Kus Irianto dan Kusno Waluyo. (2004). Gizi dan Pola Hidup sehat. Bandung: Yrama Widya.

Samsu Nurzaman. (2006). "Hubungan antara Tingkat Pengetahuan tentang Kesehatan, Status Sosial Ekonomi Orang Tua, dan Perilaku Hidup Sehat Mahasiswa Prodi PJKR FIK UNY.” Skripsi. Yogyakarta: FIK UNY.

Solita Sarwono. (1993). Sosiologi Kesehatan Beberapa Konsep Beserta amplikasinya. Yogyakarta: Gajah Mada University Press.

Soekidjo Notoatmodjo. (2007). Promosi Kesehatan dan Ilmu Perilaku. Jakarta: Rineka Cipta.

Wibowo, H. 1991. Pendidikan Kesehatan. Jakarta: Direktorat Jendral Perguruan Tinggi. Departemen Pendidikan dan Kebudayaan. 